\title{
Business Ethics and Consumer Buying: An Ethno-Regional Study in UAE
}

\author{
Indranil Bose*
}

\section{Abstract}

UAE has the largest number of expatriates from across the globe and has the presence of the largest number of products, services and brands from across the globe. Understanding the consumer consciousness or business ethicality of the products, services or the brands available is important for sustainable marketing. The present research explores the level of overall consumer consciousness about the business ethics adopted by different brands or products and whether consumer consciousness or perception remains different about the ethical practices followed by different companies, according to their places of origin. The results show that the overall consumer consciousness about the ethical practices of the products/brands available is significant and the consumer consciousness about the ethical business is different according to the regional groups.

Keywords: Business Ethics, Consumer Buying, Ethno-Regional Lines, UAE

\section{Introduction}

Since the 1980's, ethics in business has evolved as one of the most important areas of debates and discussions, which has gradually spread from the western world to a large portion of the globe. The issue of ethics in business initially evolved around the unethical

\footnotetext{
*University of Bolton, Ras Al Khaimah, UAE; sentindranil@gmail.com
} 
practices pertaining to corporate governance, social and political matters. This gradually entered the preview of other types of unethical practical issues in business in terms of labor standards, environment and sustainability issues etc. Macfarlane (1995) in his study has shown the growing impact of business related ethical discussions on different aspects of corporate decisions across the globe. Donaldson (1998) in his research has not only reflected the opinions, which are somehow similar to the opinion given by Macfarlane; but also concluded that only the organizations following ethical practices and standards can develop their businesses in the long run. DeGeorge (1990) in his study has theoretically proved the direct relationship between business sustainability and ethicality. He has shown that the organizations following the formal ethical code of conduct get greater market acceptability and widespread reputation among the stakeholders of their businesses than the organisations which do not. Paliwal (2006) in his study has developed a framework of business ethics that tries to connect the stakeholders with the concerned business organizations through respective morality principles. The author has further shown that morally engagingwith ethics identifies moral issues in business andsome of them have first evolved as essential prerequisites for sustainable growth of the business organizations in the changing global business environment. The same study has described the ways an organization gets positive impacts from the respective stakeholders by adopting appropriate ethical practices andbehaviors in their daily operations and business policies. Apart from many other positive impacts of business ethics on business, the aspects like the buying behavior have also been found to be significantly affected with the improved and sustainable adoption of business ethics by the organizations. Egan (2007) in his studies has categorically shown the marketing communication aspect of the business organizations, which have been found to be dominated by many major agenda that includes branding the organization itself. He has further shown that many of the global brands since 1980's have used business ethics as a major instrument to continuously promote their brand image in the forever growing competitive marketing environment. Clark (2004) in his studies have categorically shown that modern consumers and customers are growingly becoming concerned about the ethical 
practices such as preferring ethically produced products and services,etc. over many other factors. According to the same study, it has been mentioned that such tendencies have grown at a phenomenal rate since 1980's. It is also observed by David (2012) that though during 1980s and 1990s this tendency to prefer ethically produced products and services started to capture the attention of a number of people from the developed economies, such trends have been found to have global attention in the developing economies as well. The same study by Clark (2012) has also shown that the customers of the fashion brands and many other products and services in Asia, Europe, and America have shown their greater consciousness on the issues of ethicality that are being followed by the manufacturers and producers at different location in the world. David \& Miller (2012) have conducted an empirical study on the customer preferences of the respective brands from different geographies of the world during 1990-2000. Their research shows that the industries related to the fashion brands artifacts have remained the center of attraction of the entire debate during the same period. The study further indicated that the big brands in retail space such as Amazon, Zara, Hayward's, Adidas, etc. have shown greater commitments towards ethical compliance in procuring the supplies from different parts of the world. It was also found that, with the greater emphasis on compliance of business ethics norms by the international pressure groups and organizations as well as political and economic blocks such as European Union, ASEAN, etc., growing number of organizations involved in business have shownbudding interest on the business ethics compliance in the respective markets. Another report published by Carnegie foundation on sustainability research (2010) presented the growing policy priorities and investments by the major global players in the FMCG industries since 1990's. The report has described the pattern of such policy priorities and investments to promote different international brands as highly ethical to attract the growing number of conscious customers in many parts of the world. The same report has specifically highlighted the aspects like ethical practices and policies of different leading global brands and has discussed in detail about how such initiatives have cause positive impacts for the companies like Zara, Lenovo, Samsung,Adidas, etc. Strong (1996) in his study 
has identified the features that contribute to the growth of ethical consumerism in the sphere of marketing. It is observed that features like growing campaigns and propaganda by the social and ethical pressure groups, health related concerns, large scale information flow about any unethical practice from any nuke andcorner of the world, political and social movements etc. play a very important role in this regard. Riley (2012) in his studies has attempted to understand the decision-making process in buyer behavior. The study has also given a special mention to ethical consumerism. According to the study, ethical consumerism hasprogressively taken the center stage in the developed economies of the west and the east and the growing number of customers are even ready to spend more to encourage the organizations to procure and sell ethically obtained or manufactured products and services. This has been a phenomenal transition in the consumers' psyche since no such tendency has been observed a few decades back. Shaw \& Barry (2010), George \& Hoffman (2005), Harrison (2005), Ramos \& Abramov (2004) have shown in their respective researches about the growing importance of ethical buying, not only in the ethically disputed industries like apparel, textile, electronics, handicrafts, etc. but also in the newly discussed industries such as food processing, packaging, sweets and confectioneries, and so forth

\section{Research Problem Statement}

Business ethics and its impact on consumer buying behavior have become an important area of research and discussion globally. Many researchers have entered into the research space to study the impact of business ethics on different dimensions of consumer buying behavior. Few of them have been focused on specific industry segments and many others on specific geographies. UAE is a consumer driven economy and the heart of such consumer driven economy of UAE remains the retail sector. In the study Rinne (2001) has mentioned that almost $89 \%$ of the global brands are in retail business in UAE. The global brands include many of the world's leading organizations from the industries such as food processing, apparel and clothing, fashion and electronic appliances, retail chain, etc. A majority of such brands source their products for 
UAE markets from outside, predominantly from countries that are located in Asia and Europe. Many of these countries follow different ethical standards and the manufacturers located there comply with the local standards of ethical practice, as and when applied. The study by Galmer (2014) has shown clear differences and variations among such ethical standards practiced and complied with in different countries in Asia and Europe. Galmer in his study has also done some comparative analysis, which has shown that many such local standards are falling short of international ethical standard requirements. $\mathrm{He}$ has further discussed some of the primary reasons for such discrepancies such as inequality in norms and practices that differ from country to country as well as in diferent continents etc. However with the growing presence and effectiveness of electronic media, platforms and social networking and many other different methods, consumers across the globe have regular and easy access to all possible information pertaining to the ethical practices and standards followed by the global companies. With very strong international information connectivity and for very high standard of buying consciousness, the residence of UAE is also widely exposed to such developments in the world of ethical consumerism. According to De George (1990) the perception of business ethics remains different among the people across the globe, which is due to their different perceptions and understanding of ethical consumerism according to nationality and social segments. The same study has given anexample on the issue in the following manner, a consumer from high income group based in a country like the UK has a different perception and ethical consumerism consciousness than a middle income consumer, who is based in the Philippines. Since UAE is the country with one of the world's largest expatriate population from morethan 150 countries across the globe and has almost all leading brands in the market a systematic empirical research can be justified on the different perceptions of ethical standards of consumerism or customer buying behavior on the geographical lines. The same proposed research can also be pursued to conduct a detailed study on the impact of such business ethics perceptions on the buying behavior of the customers. 


\section{Literature Review}

The proposed study has been planned after finding the research gaps from the available literature. An attempt to review the recent studies will definitely provide an indication of the pattern of studies conducted by different scholars on the chosen areas of research and studies. One of the very important studies on the subject can be found in the work done by Ellie \& Maxon (2012). According to their study, the perception of business ethics is not a universal phenomenon and it can be different to different people due to their different nationalities, different geographies and different social backgrounds. The same study has also described the business ethics perception as the comprehensive concept by considering the aspects like ethical sourcing, ethical labor standards and employment practices, other sustainability practices etc. as viewed by the consumers. Another concept of ethical business can be found in the study by Beauchamp et al. (2009). According to their study, consumerism has evolved as a social phenomenon, where growing concerns about ethical decisions, judgments and decisions of businesses have become key considerations for the consumers in specific and for the business in general. The study has further described the business ethics not only as an evolving theoretical ideology but also well practiced phenomenon affecting the future of the business in the long run. Another study by Brenkert (2011) has argued that the essence of a business concept is a transaction for exchange of values between two or more parties, whereas such valuesare not limited only to money, goods, services and profits. The study further mentions that such valuesare also extended in the spheres of ethical satisfaction of business in terms of adopting ethical manufacturing,sourcing, delivery,operations, labor standards etc. which in turn helps in finally creating an ethical environment suitable to the business. The study by Seppanen (2013) has shown that the consumer consciousness about business ethics is a growing phenomenon across the globe. It has revealed that the buying behavior of the modern day consumers is very dependent on business ethics standards. However, the research conducted for the study was mostly concentrated in the UK and Germany, which are known as the compliant nations because of maintaining high level 
of business ethics standards and has a high level of consumer consciousness on the same matter. While conducting the study, Seppanen (2013) chose the clothing brands and it was found that a majority of the people in those countries give preference to those clothing brands with evident and proven business ethics standards compliance records. The study has also been supported by some other studies later. The study by Harrison (2014) has also shown that now a majority of the consumers in the west, mostlyof the products and services sourced from outside Europe and America, are more ethically conscious than before. Boatright (2008) has shown that many people in the west and in many developed economies in Asia are even ready to pay the extra price to buy the ethically compliant products and services, either manufactured or sourced in their home countries or from abroad. The same study has also shown that in many of the western markets, as well as in the Asian developed markets, the ethically sourced and manufactured level is priced at a relatively higher level. Many such brands, which have ethically engaged themselves in manufacturing and sourcing their products also prefer to put the sticker or the tag on such products indicating the ethical compliance to attract and impress the ethically conscious customers. A study by Egan (2007) has shown that many countries under the European Union have made it mandatory to put the sticker or the tag describing ethical compliance by the manufacturing or selling companies on the products or packages to get the permission to sell their brands or products in the markets regulated by the European Union laws. It has been found that ordinary customers from those countries are also increasingly looking for such brands and products that have ensured and declared themselves as ethically compliant. Another study by Riley (2012) has shown that the consumers regularly visiting the shopping malls and street side shopping complexes in the countries like UK, France, Luxembourg, Austria and Germany prefer ethically compliant brands more than the only reputed brands for their buying decision, this number of ethically compliant customers seem to be significantly higher in the online business arena.

The United Arab Emirates has emerged as one of the fastest growing consumer markets in the middle-east and North Africa. Different studies and reports have shown that all major consumer 
brands and products are available in the retail and the online space in this country. The available data and information have also reflected the presence of a large number of expatriates from all the continents in UAE. Therefore the need for the research on ethical influence on buyer's decision making can be easily realized. Not only that, the study pertaining to the analysis of consumer preferences towards ethically manufactured or sourced products and services according to different nationality groups should also be conducted as the findings can provide a large picture ofthe issue at the international level. No significant and detailed study on this particular aspect has been found in the context of the UAE and its market. Keeping this research gap in mind, an attempt can be made to study the same. The present research, will, therefore, contribute as a major knowledge input in understanding the level of consumer consciousness about ethical buying in the internationally significant market like UAE and it will also help to study any difference between group of nationalities residing as the expatriate in UAE in terms of their preferences of those brands and products, which have declared themselves as ethically compliant brands and products through different modes and means.

\section{Research Questions}

The following research questions have been framed according to the research purposes, as mentioned above, in the context of the research gaps identified through the brief review of the literature. The present research can, therefore, be carried out to find out the following research questions:

1. What is the level of consumer consciousness about the business ethics adopted by different brands or products?

2. Whether consumer consciousness or perception remains different about the ethical practices followed by different companies, according to their places of origin.

\section{Research Objectives}

Based on the research questions mentioned above following research objectives have been identified for the proposed research: 
1. To study the overall consumer consciousness about the ethical practices adopted by different companies or the brands available in UAE.

2. To study the level of the difference of opinion among different response groups on the products/brands preferred in line with their origin.

The first objective as mentioned above will make an attempt to understand the overall consumer consciousness about the ethical practices adopted by different companies and brands, those are available in the market of UAE. By conducting the study on this specific objective the researcher will attempt to capture the scenario regarding ethical consumerism in the market of UAE. As UAE is considered as the pioneer of modern contemporary consumerism and most of the global brands make their products and services available in UAE along with the most important global consumer driven economies at the same time, the research endeavor to study the overall consumer consciousness about the ethical practices adopted by international and regional brands and companies will definitely be considered as the significant research contribution in future. The second research objective of the proposed research will attempt to compare the difference of consciousness of the consumers based in UAE in line with the different origin and different major product categories. As already mentioned, that UAE is the home of expatriates from more than hundred countries spread across all the continents and it is known that some of the countries have the culture and practice of better ethical compliance in business and consumerism than others, a comparison in the context of the UAE will definitely be considered a watershed research initiative towards a more adequate research contribution.

\section{Research Methodology}

This is a descriptive and quantitative research. The primary data has been collected through a structured questionnaire and appropriate sampling techniques such as simple random sampling without replacement is used. The structured questionnaire had ten questions and all the questions were prepared from different available literature and studies.The questionnaire used in the 
present research included two main sections. Section Iof the questionnaire covered the demographic profile of the respondents, which has been categorized on the basis of major demographic groups residing in UAE. Six major demographic groups have been identified and included in this regard South Asian (Indian, Pakistani, SriLankan, Bangladeshi, Nepali), South East Asian (Philipina, Thai, Indonesians), East Europeans (Russians, Polish, Ukrainians etc.), Africans (Nigerians, Ugandans, Kenyans, South Africans etc.) and Westerners (British, French, Americans etc.) and Arabic speaking (Arabs). Section II of the questionnaire covered 10 questions and the responses have been captured through 5 point Likert scale, where the minimum or most negative or least response has been captured through 1 and maximum or most positive or most response is captured through 5 points.The questions under section II have been adopted with the required modification from the study by Vinai and Siriwan (2016). Once the questionnaire was prepared the same was distributed among 600 respondents based in UAE. The plan of the research was initially to collect the feedback from these 600 respondents and the questionnaire was distributed accordingly. However, a total number of 225 responses were collected in the process. According to Mathieu \&amp; Zajac (1990), $25 \%$ of the response rate can be considered as sufficiently adequate in those researches where at least 500 respondents are targeted.

As a part of the research method, indicative discussions can be presented on the formulation of the hypotheses which have been made according to the research objectives.

The first hypothesis of the proposed research is directly related to the first research objective as mentioned and discussed earlier. In the study by MacFarlane (1995), overall consumer consciousness about the ethical practices remains different but is a growing phenomenon in the different parts of the world. In relationto this observation and the first research objective of the proposed study, the following research hypothesis has been framed.

H1: Overall consumer consciousness about the ethical practices of the products/brandsavailable in the UAE is quite significant. 
The second research objective also provides support and clear guidelines to frame the second research hypothesis for the proposed research. As discussed before by De George (1990), the perception of business ethics remains different among different types of people according to their nationalities, etc. Based on this particular observation and the second research objective, the following research hypotheses have been framed for the proposed research.

H2: Consumer consciousness about ethical business varies according to their different response groups.

H3: Consumers relate the issue of business ethicality of the products/brands they prefer with the origin of such brands/ products.

From the above research hypothesis attempts have been made to capture a comprehensive picture as much as possible of the overall consumer consciousness about the ethical practices adopted by different companies or brands available in UAE, the level of differences of the consciousness of the consumers according to their different response groups and whether they relate the issue of ethical practice by their brands/products they prefer with the origin of such brands/products.

\section{Data Analysis and Findings}

Under data analysis, descriptive statistics of the respondents, the response patterns and the testing of hypotheses have been done.

From the respondents profile (Diagram 1), it has been found that $37 \%$ are South Asians (81), 18\% are from South East Asia (40), 14\% are Africans (31), 13\% are East Europeans (29), 8\% are westerners (19) and 10\% are Arabic speaking (22). 


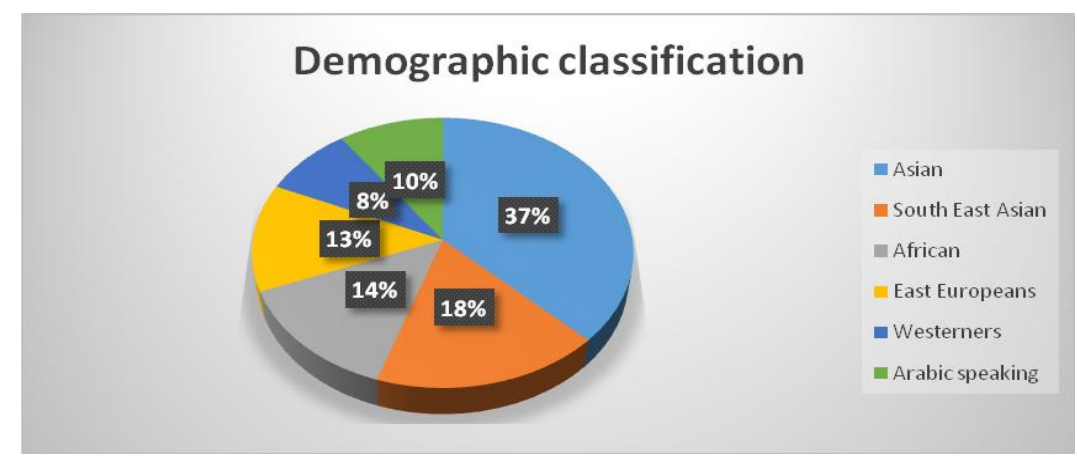

Source: Primary data

Fig 1: Demographic classification of the respondents

Based on the analysis of the captured response patterns for the ten questions, the following trends have been found (Table 1).

Table 1: Overall response pattern analysis

\begin{tabular}{|c|c|c|c|c|}
\hline No. & Question 1 & Mean & S.D. & Mode \\
\hline 1 & $\begin{array}{l}\text { I really care whether the brand/product I } \\
\text { prioritize have a reputation for ethical } \\
\text { behavior towards stockholders }\end{array}$ & 4.5 & 0.89 & 4 \\
\hline 2 & $\begin{array}{l}\text { Whether a firm is ethical to stockholders is } \\
\text { important to me in making my decision as } \\
\text { to what to buy }\end{array}$ & 4.7 & 0.42 & 4 \\
\hline 3 & $\begin{array}{l}\text { I really care whether the brands/companies } \\
\text { I prioritize have an ethical behavior } \\
\text { towards middlemen }\end{array}$ & 4.2 & 0.31 & 4 \\
\hline 4 & $\begin{array}{l}\text { I really care whether the brands/companies } \\
\text { usually have a reputation for ethical } \\
\text { behavior towards ultimate consumers }\end{array}$ & 4.6 & 0.21 & 4 \\
\hline 5 & $\begin{array}{l}\text { I really care whether the companies/brands } \\
\text { I prefer, have a reputation for ethical } \\
\text { behavior towards suppliers }\end{array}$ & 3.9 & 0.61 & 4 \\
\hline 6 & $\begin{array}{l}\text { I really care whether the companies/brands } \\
\text { I prefer, have a reputation for ethical } \\
\text { behavior towards their employees }\end{array}$ & 4.9 & 1.07 & 5 \\
\hline 7 & $\begin{array}{l}\text { I really care whether the companies/brands } \\
\text { I prefer, have a reputation for ethical } \\
\text { behavior towards the environment }\end{array}$ & 4.3 & 0.86 & 5 \\
\hline 8 & $\begin{array}{l}\text { I really care whether the companies/brands } \\
\text { I prefer, have a reputation for ethical }\end{array}$ & 3.9 & 0.57 & 3 \\
\hline
\end{tabular}


behavior towards social issues

9 I really believe that the place of origin of the brands/companies, I usually prefer, as a significant ethical determinant

10 I would pay considerably more money for a product from a company/brand that I

know to be reasonably ethical

From the above trends, it has been found that the overall consumer consciousness about the ethical practices adopted by the company and brands in the UAE is quite significant. From the highest mean and mode scores, it can be found that ethical behavior towards the employees, towards the environment, towards stockholders and towards ultimate consumers are most preferred. From the total average mean score (4.28), it is can be concluded that the overall consumer consciousness about the ethical practices of the products/brands available in the UAE is quite significant. Therefore, hypothesis 1 can be accepted.

On the question of difference in consumer consciousness about ethical business among different response groups, the following findings have been captured (Table 2). The following table also depicts the question-wise response and average response mean. 
Table 2: Difference in consumer concernson ethical business among different response groups

\begin{tabular}{cccccccc}
\hline $\begin{array}{c}\text { Questi } \\
\text { on No. }\end{array}$ & $\begin{array}{c}\text { Sout } \\
\mathrm{h} \\
\text { Asia } \\
\text { (Mea } \\
\mathrm{n})\end{array}$ & $\begin{array}{c}\text { Southe } \\
\text { ast } \\
\text { Asia } \\
\text { (Mean) }\end{array}$ & $\begin{array}{c}\text { Afric } \\
\text { an } \\
\text { (Mea } \\
\mathrm{n})\end{array}$ & $\begin{array}{c}\text { East } \\
\text { Europe } \\
\text { an } \\
\text { (Mean) }\end{array}$ & $\begin{array}{c}\text { Wester } \\
\text { ner } \\
\text { (Mean) }\end{array}$ & $\begin{array}{c}\text { Arabic } \\
\text { speaki } \\
\text { ng } \\
\text { (Mean) }\end{array}$ & $\begin{array}{c}\text { Questi } \\
\text { on } \\
\text { wise- } \\
\text { total } \\
\text { averag } \\
\text { e } \\
\text { Mean }\end{array}$ \\
\hline 1 & & & & & & & \\
2 & 3.8 & 2.9 & 2.6 & 4.1 & 4.7 & 3.4 & 3.58 \\
3 & 4.1 & 2.11 & 2.5 & 4.4 & 4.1 & 3.6 & 2.80 \\
4 & 4.2 & 2.98 & 3.1 & 4.1 & 3.8 & 3.8 & 3.66 \\
5 & 3.5 & 3.9 & 3.7 & 4.9 & 3.6 & 3.2 & 3.61 \\
6 & 4.3 & 4.1 & 3.8 & 4.4 & 4.1 & 3.9 & 3.88 \\
7 & 3.8 & 3.9 & 3.4 & 3.7 & 4.3 & 3.2 & 3.98 \\
8 & 4.1 & 3.2 & 2.9 & 4.1 & 4.1 & 3.2 & 3.81 \\
9 & 4.2 & 3.7 & 3.5 & 4.3 & 4.4 & 4.1 & 4.03 \\
10 & 3.3 & 3.7 & 3.1 & 3.9 & 4.3 & 3.9 & 3.70 \\
Group & 3.9 & 3.36 & 3.24 & 4.11 & 4.15 & 3.61 & \\
wise & & & & & & & \\
total & & & & & & & \\
average & & & & & & & \\
Mean & & & & & & & \\
\hline
\end{tabular}

From the analysis, it can be observed (Table 2) that the consumer consciousness about ethical business varies according to their different response groups. Overall, westerners are found to be most concerned (average mean score 4.15) about the ethical business practices by different brands or products, those available in UAE. They are followed by the East Europeans (average mean score 4.11), South Asians (average mean score 3.9), Arabic speaking respondents (average mean score 3.61), East Asians (average mean score 3.36) and Africans (average mean score 3.24). The following image (Figure 2) clearly reflects the response group-wise trends and it clearly proves that the difference in consumer concerns on ethical business among different response groups that prevails in UAE. Therefore hypothesis 2 is found to be accepted. 


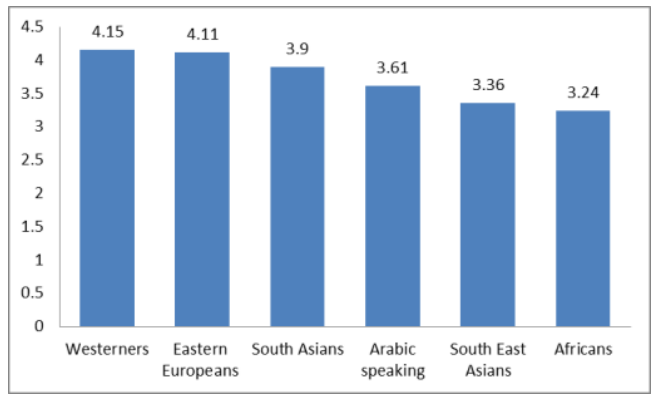

Source: Primary data

Diagram 2: Difference in consumer concerns on ethical business among different response groups

Hypothesis 3 has been framed to test, whether the consumers relate the issue of ethicality of the products/brands they prefer with the origin of such brands/products. This hypothesis also seems to be accepted as the mean score of the response pattern has been calculated as 3.7, with the mode score of 4 , which is quite high (Table 2). However, the difference in perception in this regard can be easily understood from the responses received on the same question (question 9 in the questionnaire) in line with different response groups. From the research findings and analysis, it can be said that the westerners are more inclined to the perception of origin based business ethicality of specific brands/products (mean 4.4), followed by the east Europeans (mean 4.3), South Asians (mean 4.2), Arabs/Arabic speakers (mean 4.1), South East Asians (mean 3.7) and Africans (mean 3.1) (refer Table 2/ Figure 3).

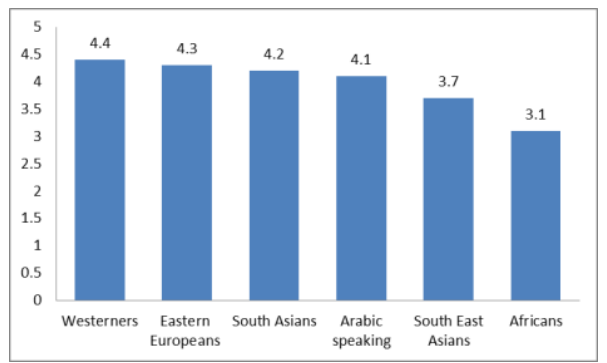

Source: Primary data

Diagram 3: Pattern of inclination to the perception of origin based business ethicality of specific brands/products 
From the above analysis, it has been found that all the hypotheses can be accepted (refer table 3 )

Table 3: Results of Hypotheses Testing

\begin{tabular}{clc}
\hline $\begin{array}{c}\text { Hypothesis } \\
\text { no. }\end{array}$ & \multicolumn{1}{c}{ Statement of Hypotheses } & Results \\
\hline $\mathrm{H} 1$ & $\begin{array}{l}\text { Overall consumer consciousness about the } \\
\text { ethical practices of the products/brands } \\
\text { available in the UAE is quite significant. } \\
\text { Consumer consciousness about ethical } \\
\text { business varies according to their different } \\
\text { response groups. }\end{array}$ & Accepted \\
& $\begin{array}{l}\text { Consumers relate the issue of the business } \\
\text { ethicality of the products/brands they prefer } \\
\text { with the origin of such brands/products. }\end{array}$ & Accepted \\
\hline
\end{tabular}

\section{Conclusion and Observation}

The present research has categorically shown that the overall consumer consciousness about the ethical practices of the products/brands available in the UAE is quite interestingly significant. However, when, the consumer consciousness about the ethical business is concerned, opinions or perceptions are found to be different in line with the regional groups. Westerners have been found most concerned and they maintained the strongest inclination towards the issue, whereas the Africans respondents have shown the weakest inclination and concern. Even on the issue of consumers' tendency to relate to the issue of business ethicality of the products/brands, westerners are found to be most concerned.

\section{Limitations and Future Scope of Research}

The present research is an attempt to enrich the literature on business ethicality from the consumers' perspectives. This can be claimed as a unique endeavor as no previous study can be found on the specific subject in the geographical context, i.e. UAE and in the cultivated research scope, the present study has attempted to address. However, this research cannot be claimed as the end of the academic endeavor on the addressed subject areas. The limitations 
of the present research, therefore, can be considered as the possible exposition of future studies. Not only have a very limited number of samples been covered in the present research, but also the response collection through a self-service questionnaire cannot be completely foolproof as a very minimum chance of duplication of data remains always. Though an attempt has been made to ensure genuine feedback by following all recommended methods. The present research can be further enhanced in scale and scope by adding more dimensions and criticality such as specific product/brand/service wise customer perception analysis on business ethicality. The study can be conducted to compare the issues and subjects by comparing the consumers' opinion of different countries, located in the MENA region as the entire place is considered as the major concentrations of international brands and a large number of expatriates. Areas like economic, social and cultural dimensions and their impact on the consumer perception towards business ethicality on different ethnic clusters can also be conducted. However, the significance of the present research cannot be shown in poor light as it has been an endeavor towards a much broader research process. The findings of the present research should definitely be considered as a very significant initial effort in this direction of continuous endeavors.

\section{References}

Beauchamp T.L., Browie N.E., \& Arnold D.G. (2009). Ethical theory and business. London, UK: Pearsons.

Belgrave, L.L., \& Seide, K. (2018). Grounded theory methodology: principles and practices. Handbook of Research Methods (pp. 1-18).

Boatright, J. (2008). Ethics and the conducts of business. Prentice Hall.

Brenkert D. D. (2011). Marketing ethics. Journal of Business, 9(1), 101-112.

Bryman, A., \& Bell, E. (2007). Business research methods (2nd ed). New York, NY: Oxford University Press Inc.

Clark, D. (2004). The rough guide to ethical shopping.New York, NY: Rough Guides.

Clark, D. (2012). Ethical marketing and sustainability strategy. New York, NY: Rough Guides.

David, F. \& Miller, M. (2012). Branding through sustainability. Journal of Marketing Management, 3(4), 319-330.

David, F. (2012). Nationality and ethical choices in consumer behaviour. Journal of Marketing Management, 3(2), 236-240. 
DeGeorge, R. (1990). Business ethics. New York, NY: MacMillan.

Donaldson, C. (1998). Marketing principles and sustainability. Philadelphia: Ecco Publications.

Egan, J. (2007). Marketing communications. Thomson.

Ellie. J., \& Maxon, F. (2012). Ethical choices in consumer behavior. Journal of International Marketing, 12(2), 203-216.

Galmer, J. (2014). Ethical standards and consequences in marketing. Ecco Publications.

George, H., \& Hoffman, M. (2005). Marketing ethics: readings and cases. New York, NY: Brooklyn Books.

Harrison, M.R. (2005). An introduction to business and management ethics. Palgrave Macmillan.

Harrison, M.R. (2014). Ethical sustainability in contemporary marketing. Journal of Sustainable Business,11(2), 209-219.

Macfarlane, B. (1995). Business ethics: Too little, too late. Education+ Training, 37(5), 32-36.

Mathieu, S., \& Zajac, N. (1990). Research methodology in business (2nd ed.). Thomson, London: Brooks.

Palliwal, K. (2006). Ethical Challenges in business. Journal of Marketing Dynamics,40(2), 230-241.

Quinlan, J. A., Neath, I., \& Surprenant, A. M. (2019). Positional uncertainty in the Brown-Peterson paradigm. Canadian Journal of Experimental Psychology, 15(1), 219-240.

Ramos, A.,\& Abramov, H. (2004). New dynamics in sustainability. Journal of Marketing Management, 12(2), 136-147.

Rilley, J. (2012). Buyer behaviour-The decision-making process. Available at: http://tutor2u.net/ business/marketing/ buying_decision_ process.asp [April 15, 2019].

Rinne, J. (2001), factors affecting the prediction of the performance of the global brands in uae Retail Markets. Journal of Middle East Management and Marketing, 10(1), 612-630.

Shaw, W.H., \& Barry, V. (2010). Moral issues in business (11th ed.). Wadsworth, Belmont.

Stein, M. (2018). Research methodology. London: Business Dimension.

Strong, C. (1996). Features contributing to the growth of ethical consumerism-a preliminary investigation. Marketing Intelligence $\mathcal{E}$ Planning, 14(5), 5-13. 